\title{
ENHANCING LSRW SKILLS THROUGH COMMUNICATIVE LANGUAGE TEACHING
}

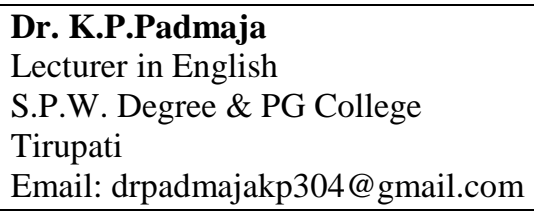

With the advent of information technology the need for good communication skills in English is ever-growing. It is also creating a huge demand for the teaching of English language in this global village. Due to this, the learning of English language has become a prerequisite qualification for every $21^{\text {st }}$ century man who would like to improve their English language and get command over it.

Teaching should be learner centered and task oriented rather than teacher centered methods. If the students do not use the language they cannot learn the language. The only way to develop communication skills is through practice. So it is necessary to create a suitable environment in the classrooms to develop communication skills.
At present communicative language teaching is one of the most suited and most popular method to reach English language to learners. It promotes learning by making the students more active, more involved and more responsible. In this methodology the student talk time is more and the teacher role become more of a facilitator. The language is taught through task based activities to make the students communicatively competent.

Communicative language teaching is used not only to improve the oral skills of a learner but it can be used even to improve the other skills like listening, reading and writing. In fact, it puts great emphasis on listening which implies an activity to understand other skills. Unlike the audiolingual method of language teaching, which 
ELK

Asia Pacific Journals

relies on repetition and drills, it leaves the

learners in suspense to the outcome of a

class exercise, which will vary according to

their reactions and responses.

Communicative approach heartens the judicious use of the language and exchange of knowledge and therefore broadens the thinking faculty of the learners to strengthen their expression. Communicative activity enlightens students responsibility in the participation of a performance in the class. It in largely done through speech and therefore students raise of voice to make it audible to every presenter in the classroom. Because of the increased responsibility to participate, students may feel that they gain confidence in using the target language in general. They also feel that they are more responsible manager of their own learning (Larsen Freeman 1986)
ELK Asia Pacific Journals - Special Issue ISBN: 978-81-930411-1-6

Obviously, learner is the leading light in learning process and fruits of learning are witnessed when the process of learning is not felt as a onerous activity. The learners feel thrilled to participate in the activities that are set by the teachers, which they usually encounter in their regular life. This is the method, through which, many of their doubts regarding facing certain situations are classified students feel contented because their communication problems, which make them embarrassed are solved. The teacher continues to create more and more real life situations in the classroom and train the students to make themselves affiable through spoken language and communicative language.

Another note worthy attribute of CLT "its learner centered and experience based teaching". In the CLT class the teachers, along with the students are managers of learning. The teacher does not 
ELK

Asia Pacific Journals

play the role of a dictator, orator, administrator or ruler but an organizer, facilitator and enlightener and saviour, therefore the students feel relaxed and confident and learning under such circumstances gains momentum.

In the classroom, the teacher sets different tasks and activities to encourage the students to communicate in English using the language they have already learnt. For example, they exchange information, discuss and solve problems in pairs or groups. Sometimes students struggle to understand and be understood, but this is part of the learning process. The teacher does not always correct mistakes.

The learners who have little exposure to speaking will feel free and enthusiastic to express themselves in the target language. They develop real communication skills as they are allowed to speak about their own ideas, opinions and
ELK Asia Pacific Journals - Special Issue

ISBN: 978-81-930411-1-6

real life situations. It helps them to become more accurate and fluent in English. Pair and group work are some of the teaching learning techniques often used extensively in communicative language teaching.

Pair work and group work allows all students to practice language and to actively participate. It involves the whole class working separately in pairs or small groups. It teaches students to helps each other with their learning. As penny ur states.

A word about the activities which the teacher may conduct in the classroom to improve the communication skills of the learners. One of the goals of communicative language teaching is to develop fluency in language use. It can be developed by creating classroom activities in which students must negotiate meaning, use communication strategies, correct misunderstandings, and work to avoid communication break downs. 
ELK

Asia Pacific Journals

Activities focusing on fluency reflect

natural use of language, focus on achieving communication, require meaningful use of language, require the use of communication strategies, produce language that may not be predictable, and seek to link language use to context, while activities focusing on accuracy reflect classroom use of language focus on the formation of correct examples of language, practice language out of context practice small samples of language, do not require meaningful communication.

The tasks which improve the learners fluency and accuracy of the language.

Role Play: A group of students of mixed language ability carry out a role play in which they have to adopt specified roles and personalities provided for them on cue cards. These roles involve the drivers, witnesses and the police at a collision between two cars. The language is entirely improvised by the students, though they use
ELK Asia Pacific Journals - Special Issue ISBN: 978-81-930411-1-6

heavily constrained by the specified situation and characters.

Dialogues: Students should involve themselves in conversation and practice dialogues. The dialogues may contain examples of falling intonation in whquestions. The class is organized in groups and each group consisting of three, two students practicing the dialogue, and the third, who is rather good at English, playing the role of monitor. The monitor checks that the others are using the correct intonation pattern and corrects them where necessary. The students rotate their roles between those speaking the dialogue and those monitoring. The teacher moves around listening the groups and correcting their language where necessary. While organizing such activities teachers recommend the learners to use a balance of fluency activities and accuracy and to use accuracy activities to support fluency activities. For example, based on 
ELK

Asia Pacific Journals

students performance on a fluency task, the teacher could assign accuracy work to deal with grammatical or pronunciation problems the teacher observes while students were carrying out the task.

Jigsaw activities: Jigsaw activities are also based on the information-gap principle. Typically the class is divided into groups and each group has part of the information needed to complete an activity. The class must fit the pieces together to complete the whole. In doing so, they must use their language resources to communicate meaningfully and take part in meaningful communication practice.

Examples:- (a) The teacher takes a narrative and divides it into twenty sections (or as many sections as there are students in the class) Each student gets one section of the story. Students must then move around the class and by listening to each section read aloud, decide where in the story their
ELK Asia Pacific Journals - Special Issue ISBN: 978-81-930411-1-6

section belongs. Eventually the students have to put the entire story together in the correct sequence.

(b) The teacher prepares three different listening tasks, one focusing on each of the three speaker's points of view. Students are divided into three groups and each group listens and taken notes on of the three speakers opinions students are then rearranged into groups containing a student from groups $\mathrm{A}, \mathrm{B}$ and $\mathrm{C}$. They now roleplay the discussion using the information they obtained.

\section{Task completion activities like} puzzles, games, map-reading and information gathering and sharing activities such as student conducted surveys interviews etc. are some other activites which can be used in communicative language teaching. Through these activities, it is believed that the learners will obtain several benefits like learning from hearing 
ELK

Asia Pacific Journals

the language used by other members of the group, producing a greater amount of language.

To conclude, one may say that the communicative language teaching is universally appropriate and benefits the students in a variety of ways by improving their knowledge on vocabulary, structures and functions as well as strategies to enable them to interact successfully in the target language. The teacher plays a crucial role is it as he has set up the activities in which the communication actually happens. A noteworthy attribute of CLT is it is learnercentered and experience based teaching. Thus, we can say that the approach is more relevance in this highly tough teaching world and offer a lot to the EFL teacher.

\section{References}

[1] Jack C. Richards, Communicative Language Teaching Today,
ELK Asia Pacific Journals - Special Issue ISBN: 978-81-930411-1-6

Cambridge. Cambridge University

Press, 2006.14

[2] Richard J.C., and Rodgers, T.S. "Approaches and Methods in language teaching”

[3] Littlewood, W (1981) "Communicative language teaching”. New York: Cambridge University Press.

[4] Ur, penny. A course in language Teaching: practice and Theory. Cambridge: Cambridge University press 2005.121. 